УДК 159.9.07

\author{
Шаилова Анастасія, \\ ORCID iD 0000-0001-8634-6990 \\ методист обласного ресурсного иентру \\ з підтримки інклюзивної освіти \\ Миколаӥвський обласний інститут \\ післядипломної педагогічної освіти \\ вул. Адміральська, 4-а, 54001, м. Миколаїв, Украӥна \\ anastasiia.shashlova@moippo.mk.ua
}

\title{
СУЧАСНІ МЕТОДИ ДІАГНОСТИКИ РІВНЯ РОЗВИТКУ ДІТЕЙ З ОСОБЛИВИМИ ОСВІТНІМИ ПОТРЕБАМИ
}

У статті проаналізовано особливості проведення комплексної психолого-педагогічної оцінки розвитку дитини з особливими освітніми потребами в умовах інклюзивно-ресурсного иентру із застосуванням сучасних психодіагностичних методик, які відповідають міжнародним стандартам психодіагностики та адаптовані до використання на територї Украӥни.

Охарактеризовано комплект лічензійного психодіагностичного інструментарію для дослідження рівня розвитку дітей, які мають особливості психофізичного розвитку, рекомендований для проведення комплексної оцінки розвитку дітей в умовах інклюзивно-ресурсного иенттуу.

Запропоновано алгоритм роботи практичного психолога щуодо здійснення оцінки когнітивної та емоційно-вольової сфер дитини в процесі проведення комплексної психолого-педагогічної оцінки розвитку дитини з особливими освітніми потребами із застосуванням комплекту психодіагностичних методик.

Ключові слова: діти з особливими освітніми потребами; індивідуальні особливосmi; комплексна психолого-педагогічна оцінка розвитку; особливості психофізичного розвитку; психодіагностичне дослідження; психодіагностичні методики.

(C) Шашлова А. Л., 2021

Вступ. У сучасних умовах розвитку освіти в Україні, зокрема поширення інклюзивної освіти, важливою є реалізація таких підходів у освітньому процесі, які б забезпечували повноцінні умови для здобуття якісної освіти всіма дітьми незалежно від наявних психофізичних особливостей. 3 огляду на різноманітність таких особливостей розвитку виникає питання визначення певних відправних точок розвитку дитини для побудови іiі індивідуальної освітньої траєкторії та системи психолого-педагогічного впливу. Визначення відправних точок розвитку дитини забезпечується у процесі проведення психолого-педагогічного оцінювання іiі функціонування й відповідності такого функціонування певним віковим

нормам.

За твердженням Т. I. Ілляшенко, одним із найважливіших завдань у комплексній оцінці розвитку дитини є визначення всього комплексу психолого-педагогічних проблем конкретної дитини та позитивних сторін іiі розвитку для формування подальшого корекційного впливу та визначення умов їі психологічного супроводу в процесі навчання (Ілляшенко Т., 2020, с. 96).

Проведення якісного психолого-педагогічного оцінювання рівня розвитку дітей, зокрема дітей з особливими освітніми потребами, є однією з основних умов організації процесу навчання, а саме:

- постановка адекватних цілей для всіх учнів; 
- усування різноманітних бар'єрів у навчанні;

- адаптація середовища й матеріалів до можливостей дитини;

- складання корекційних та індивідуальних програм розвитку;

- підтримка кожної дитини та максимальне розкриття іiї потенціалу.

Серед широкого діапазону психодіагностичного інструментарію, яким володіють психологи-практики, наявність методів дослідження інтелектуальних функцій, а також особливостей проявів інших специфічних порушень $є$ недостатнім.

На нашу думку, наразі актуальним $€$ питання забезпечення фахівців інклюзивно-ресурсних центрів сучасними методиками дослідження інтелектуальних здібностей, когнітивних процесів дитини, а також методами діагностики проявів таких найпоширеніших порушень психофізичного розвитку, як: розлад дефіциту уваги та гіперактивності, розлади аутистичного спектра, порушення інтелектуального розвитку тощо.

\section{Аналіз основних досліджень 3 про- блеми.}

Наукове, теоретичне та експериментальне обгрунтування важливості проведення психодіагностичного дослідження індивідуальних особливостей розвитку дітей, таких, як: інтелектуальні здібності, когнітивні процеси, емоційно-вольова регуляція для ефективного планування психолого-педагогічного впливу та постановки адекватних цілей навчання, є одним із важливих напрямів сучасної корекційної педагогіки та спеціальної психології.

На необхідності проведення такого діагностування наголошували вчені Л. Венгер, 3. Гільбух, О. Стребелєва, Н. Стадненко, Т. Ілляшенко, А. Обухівська. Так Л. Венгер вивчала дослідження пізнавальних процесів дитини дошкільного віку для вивчення можливості оволодіння опосередкованим розв'язанням пізнавальних задач; 3. Гільбух розглядала процес вивчення темпераменту, пізнавальних процесів молодшого школяра як основи ефективного оволодіння знаннями; О. Стребелєва вважала раннє виявлення несприятливих факторів розвитку дитячої психіки запорукою побудови вчасного корекційного впливу та підготовки дитини до школи; Н. Стадненко, Т. Ілляшенко та А. Обухівська запропонували експрес-методику дослідження розумового розвитку дітей та його оцінки залежно від мір допомоги експериментатора.

Метою статті $\epsilon$ висвітлення інформації про сучасні, всесвітньо визнані, психодіагностичні методики якісного дослідження рівня розвитку дітей з особливими освітніми потребами, адаптовані на території України.

Означена мета потребує виконання таких завдань:

- представлення особливостей проведення комплексної психолого-педагогічної оцінки розвитку дитини 3 особливими освітніми потребами;

- характеристика комплекту психодіагностичних методик, адаптованих на території України, для проведення комплексної оцінки розвитку дітей із особливими освітніми потребами в умовах інклюзивно-ресурсного центру;

- висвітлення орієнтовного алгоритму застосування комплекту психодіагностичних методик для проведення психодіагностичного дослідження індивідуальних особливостей дітей у процесі здійснення комплексної оцінки розвитку дитини з особливими освітніми потребами.

Виклад основного матеріалу.

Провідною базовою потребою дітей 3 особливими освітніми потребами, як і для їхніх однолітків із нормотиповим розвитком, є необхідність у розвитку і навчанні. Реалізація освітніх потреб дітей із психофізичними порушеннями, їхня суспільна адаптація значною мірою залежать від урахування в освітньому процесі індивідуальних особливостей розвитку, зокрема інтелектуальних можливостей, ступеня збереження когнітивного і соціального 
функціонування та вчасно розпочатої корекційно-розвиткової допомоги.

Нині в Україні створено потужну мережу інклюзивно-ресурсних центрів, до повноважень яких віднесено здійснення комплексної психолого-педагогічної оцінки розвитку дитини (далі - Комплексна оцінка).

Проведення якісної Комплексної оцінки є надзвичайно важливим для визначення оптимального освітнього маршруту та побудови індивідуальної освітньої траєкторії дитини з особливими освітніми потребами.

Комплексна оцінка розвитку дитини виконує низку завдань, зокрема:

- визначення особливих освітніх потреб дитини;

- визначення особливостей психофізичного розвитку дитини, іiї сильних та слабких сторін;

- розроблення рекомендацій щодо освітньої програми дитини, особливостей пристосування освітнього середовища, потреби в індивідуальній програмі розвитку, а також надання психолого-педагогічних, корекційно-розвиткових послуг дитині;

- розроблення рекомендацій щодо організації освітнього процессу дитини для адміністрації закладу освіти, педагогічних працівників, батьків або законних представників дитини (Постанова Кабінету Міністрів України № 545 «Про затвердження Положення про інклюзивно-ресурсний центр», 2017 р.).

Проведення якісного психолого-педагогічного оцінювання рівня розвитку дітей 3 особливими освітніми потребами потребує застосування у професійній діяльності практичного психолога інклюзивно-ресурсного центру психодіагностичного інструментарію, який би відповідав світовим стандартам психодіагностики та індивідуальним запитам кожної родини.

Зарубіжний досвід психодіагностичних досліджень демонструє наявність успішних світових практик, які доцільно застосовувати в роботі з дітьми щодо дослідження інтелектуальних здібностей, пам'яті, уваги, розладу дефіциту уваги та гіперактивності, проблем із соціальною взаємодією, персеверацій, соматосенсорних порушень, порушення спілкування та розвитку, розладів настрою, когнітивного вербального/довербального спектра, експресивного розвитку, рецептивного мовлення, дрібної моторики, великої моторики, візуально-моторного наслідування, дезадаптивних форм поведінки тощо.

2018 року за сприяння Міністерства освіти і науки України інклюзивно-ресурсні центри забезпечені ліцензійним інструментарієм для дослідження рівня розвитку дітей 3 особливими освітніми потребами (комплект методик для визначення рівня розвитку дітей під час проведення комплексної психолого-педагогічної оцінки), який відповідає міжнародним стандартам психодіагностики та адаптований до використання на території України.

Застосування таких психодіагностичних інструментів дозволяє досліджувати прояви найпоширеніших нині особливостей розвитку дітей, які мають значний вплив на успішність їхнього навчання та соціалізації.

Комплект психодіагностичних методик для проведення комплексної оцінки розвитку дітей практичними психологами інклюзивно-ресурсних центрів містить п'ять психодіагностичних інструментів:

- методики для визначення рівня інтелектуального розвитку дитини: Шкала інтелекту Векслера для дітей IV видання (WISC-IV) та Міжнародна шкала продуктивності Лейтера третього видання (Leiter-3);

- методики, спрямовані на вивчення особливостей розвитку та пізнавальної активності дітей із розладами аутистичного спектра; - індивідуалізоване психоосвітнє оцінювання дітей із розладами аутистичного спектра за методикою TEACCH (РЕР-3) та Скринінгова шкала розладів аутистичного спек- 
тра (CASD);

- психодіагностичний опитувальник для виявлення наявності в дитини розладу дефіциту уваги з гіперактивністю (РДУГ) - Шкали Коннерс третього видання (Conners-3).

Розглянемо характеристики кожної 3 методик докладніше.

Шкала інтелекту Векслера для дітей IV видання (WISC-IV) - це клінічний інструмент для оцінки інтелектуальних здібностей дітей у віці від 6 до 16 років 11 місяців. Цей тест проводиться в індивідуальному порядку, тобто окремо з кожним респондентом. Методика WISC-IV спрямована на вивчення показників інтелектуального функціонування дитини в конкретних когнітивних сферах, а також сумарного показника інтелекту (тобто загального показника IQ) (Векслер Д., 2018). Результати проведення діагностики дають інформацію про особливості інтелектуального функціонування дитини: вербальний інтелект, сприйняття i мислення, швидкість оброблення інформації, робочу пам'ять тощо.

Шкала інтелекту Векслера для дітей IV видання дозволяє оцінити наявні вроджені здібності людини, опосередковані біологічно зумовленими властивостями мозку, які відповідають за спонтанне научіння у процесі взаємодії людини з середовищем, здатність до дедукції та індукції, узагальнення тощо (текучий інтелект), а також набуті в ході культурного і соціального досвіду когнітивні знання і навички (кристалізований інтелект).

Шкала продуктивності Лейтера третьго видання (Leiter-3) - індивідуально-орієнтований тест, створений для дослідження когнітивних функцій у дітей та дорослих від 3 до 75 років і старше. Ця методика дає можливість вивчення невербального інтелекту та візуалізації, невербальної пам'яті, уваги та здатності до подолання когнітивних перешкод. Особливістю методики Leiter-3 є невербальна форма подачі інструкцій і завдань, що дозволяє досліджувати когнітивні здібності в осіб із комунікативними розладами, моторними порушеннями, розладом дефіциту уваги та гіперактивності, з аутизмом, порушеннями мовлення та слуху, порушеннями внаслідок органічного ушкодження головного мозку, а також осіб різних рас і національностей, які не володіють українською мовою. Методика Leiter-3 досліджує інтелектуальні здібності, неопосередковані мовленнєвим розвитком.

Методика РЕР-3 розроблена на основі програми «ТЕАССН» (міжнародно визнана комплексна програма для навчання та роботи $з$ дітьми з розладами аутистичного спектра та іншими розладами) і вузько спрямована на діагностику рівня розвитку дітей із розладами аутистичного спектра. Результати проведення діагностичного дослідження за допомогою РЕР-3 дають можливість підтвердження діагнозу РАС, визначення ступеня тяжкості відхилення; дозволяють оцінити рівень розвитку нерівномірно представлених сильних і слабких сторін дитини в контексті навчання, характерних для розладів аутистичного спектра та пов'язаних із ним порушень розвитку, установити віковий рівень розвитку дитини в різних сферах, а також оцінити ефективність педагогічної та клінічної корекції в динаміці. Методика дає можливість визначити рівень розвитку навичок і надає інформацію для визначення найближчої зони розвитку дитини, що особливо важливо для побудови подальшої програми втручання.

Tecm CASD (Скринінгова Шкала розладів аутистичного спектра) пропонує швидкий і надійний метод діагностики аутизму в дітей від 1 до 16 років без урахування вікової категорії, рівня розумового розвитку або ступеня прояву розладу (Маєс С., 2013). Ця методика дозволяє оцінити наявність/відсутність у дитини основних і супутніх симптомів аутизму, та за їхньою кількістю зробити висновок про ймовірність у дитини розладу аутистичного спектра.

Психодіагностичний опитувальник Conners -3 (Шкали Коннерс, 3 версія) - це клінічний тестовий опитувальник, який $\epsilon$ узагальненим результатом багаторічного дослідження в галузі дитячої та юнацької психопатології та дозволяє проводити діа- 
гностику розладу дефіциту уваги і гіперактивності (РДУГ) і його найпоширеніших супутніх проблем і розладів. Методика $\epsilon$ адаптованою для України, має високу валідність та відповідає критеріям DSM-5 (Діагностичний і статистичний посібник 3 психічних розладів п'ятого видання (англ. Diagnostic and Statistical Manual of mental disorders). Опитувальник являє собою мультиінформативну оцінку функціонування дітей і підлітків між 6 і 16 роками, що враховує домашню, соціальну та шкільну обстановку, і дає інформацію для визначення проблем у навчанні, планування терапевтичного втручання і моніторингу.

Conners-3 дає вичерпну та сфокусовану інформацію щодо оцінки РДУГ для ухвалення рішень в клінічному діагностуванні та для визначення придатності дитини до навчання, при плануванні терапевтичного втручання і моніторингу (Keith Conners C., 2017). За результатами дослідження методикою Conners-3 можна визначити ймовірність наявності в дитини РДУГ, його типу, а також сильні та слабкі сторони розвитку дитини як основи для складання подальшого освітнього маршруту, індивідуальної програми розвитку та планування психолого-педагогічних і корекційно-розвиткових послуг.

На сьогоднішній день використання саме цього комплекту психодіагностичних методик рекомендується практичним психологам інклюзивно-ресурсних центрів для визначення рівня розвитку дітей під час проведення комплексної психолого-педагогічної оцінки. Для оволодіння необхідним набором навичок у роботі з методиками практичні психологи інклюзивно-ресурсних центрів мають пройти відповідне навчання, а також процедуру сертифікації (Векслер Д., 2018).

Узагальнена інформація щодо основних характеристик методик психодіагностичного дослідження для проведення комплексної оцінки розвитку дітей з особливими освітніми потребами представлена в Таблиці 1.

Таблиия 1

\section{Інструменти}

психодіагностичного дослідження для проведення комплексної оцінки розвитку дітей з особливими освітніми потребами, адаптовані для використання в Україні

\begin{tabular}{|c|c|c|c|c|}
\hline $\begin{array}{l}\text { № } \\
\text { 3/II }\end{array}$ & Назва методики & На що направлена & $\begin{array}{l}\text { Віковий } \\
\text { діапазон }\end{array}$ & Форма проведення \\
\hline 1. & $\begin{array}{c}\text { Методика для } \\
\text { вимірювання } \\
\text { інтелекту дітей } \\
\text { WISC-IV } \\
\end{array}$ & $\begin{array}{c}\text { Дослідження інтелектуальних } \\
\text { здібностей }\end{array}$ & $\begin{array}{l}\text { Діти віком } \\
\text { від } 6 \text { до } \\
16 \text { років }\end{array}$ & $\begin{array}{c}\text { Низка субтестів, які } \\
\text { містять як вербальні, } \\
\text { так і невербальні } \\
\text { завдання } \\
\end{array}$ \\
\hline 2. & $\begin{array}{c}\text { Методика } \\
\text { дослідження } \\
\text { невербального } \\
\text { інтелекту Leiter-3 }\end{array}$ & $\begin{array}{c}\text { Оцінка невербального інтелекту } \\
\text { і функціонування } \\
\text { нейропсихологічних процесів, } \\
\text { що лежать в його основі }\end{array}$ & $\begin{array}{l}3-75+ \\
\text { рокiв }\end{array}$ & $\begin{array}{c}\text { Низка субтестів із } \\
\text { невербальними } \\
\text { завданнями }\end{array}$ \\
\hline 3. & $\begin{array}{l}\text { Діагностика розладу } \\
\text { дефіциту уваги і } \\
\text { гіперактивності за } \\
\text { допомогою } \\
\text { методики Conners-3 }\end{array}$ & $\begin{array}{c}\text { Оцінка розладу дефіциту уваги і } \\
\text { гіперактивності (РДУГ), супутніх } \\
\text { проблем і розладів у дітей та } \\
\text { підлітків (тривожність та депресія, } \\
\text { труднощі із навчанням, опозищійний } \\
\text { розлад непокори, порушення } \\
\text { поведінки) }\end{array}$ & 6-16 років & $\begin{array}{l}\text { Опитувальник, що } \\
\text { містить } 3 \text { форми: } \\
\text { для дітей; } \\
\text { для батьків; } \\
\text { для педагогів }\end{array}$ \\
\hline 4. & $\begin{array}{c}\text { Індивідуалізоване } \\
\text { психоосвітнє } \\
\text { оцінювання дітей із } \\
\text { розладами } \\
\text { аутистичного } \\
\text { спектра РЕР-3 }\end{array}$ & $\begin{array}{c}\text { Дозволяє оцінити сукупність } \\
\text { нерівномірно представлених } \\
\text { сильних і слабких з погляду } \\
\text { навчання сторін дитини, } \\
\text { характерних для розладів } \\
\text { аутистичного спектра та пов'язаних } \\
\text { із ним порушень розвитку }\end{array}$ & $2-7,5$ років & $\begin{array}{c}\text { Містить завдання для } \\
\text { виконання дитиною } \\
\text { та опитувальник для } \\
\text { батьків/опікунів }\end{array}$ \\
\hline 5. & $\begin{array}{c}\text { Скринінгова шкала } \\
\text { розладів } \\
\text { аутистичного } \\
\text { спектра CASD }\end{array}$ & $\begin{array}{c}\text { Швидкий скрннінг наявності } \\
\text { симптомів розладу } \\
\text { аутистичного спектра }\end{array}$ & $\begin{array}{l}\text { Для дітей } \\
\text { від } 1 \text { до } \\
16 \text { років }\end{array}$ & $\begin{array}{c}\text { Опитувальник для } \\
\text { батьків/опікунів }\end{array}$ \\
\hline
\end{tabular}

Джеерело складено автором самостійно 
Процес організації та проведення комплексної психолого-педагогічної оцінки розвитку дитини з особливими освітніми потребами передбачає виконання роботи 3 дитиною та їі батьками або законними представниками за декількома етапами, одним $з$ яких є здійснення оцінки когнітивної та емоційно-вольової сфер із застосуванням комплекту психодіагностичних методик.

Для здійснення якісного психодіагностичного дослідження когнітивної та емоційно-вольової сфер із застосуванням комплекту психодіагностичних методик робота практичного психолога може бути представлена такими кроками:

1. Проведення первинного інтерв'ю 3 батьками або законними представниками дитини 3 метою з'ясування запиту сім'ї. Під час бесіди варто встановити довірливі відносини, щоб отримати достовірні відомості про особливості поведінки дитини. Треба уважно вислухати, що турбує батьків у розвитку їхньої дитини, з'ясувати, у яких сферах дитина має найбільше труднощів та яким чином вони проявляються.

2. Вивчення історії народження та розвитку дитини, наявної документації (iсторія розвитку дитини/амбулаторна карта, характеристики 3 місця навчання/виховання, письмові роботи, малюнки) 3 метою з'ясування наявних труднощів.

3. Визначення набору необхідного інструментарію для проведення психодіагностичного дослідження з урахуванням запиту родини та наявних труднощів у дитини (таблиця 1).

4. Безпосереднє проведення психодіагностичного дослідження 3 використанням методик для проведення комплексної оцінки розвитку дітей з особливими освітніми потребами. Проведення психодіагностичного дослідження передбачає ознайомлення батьків 3 процедурою проведення тестування, наголошення на важливості самостійного виконання дитиною завдань та безпосереднє дослідження. Також важливою умовою проведення якісного дослідження $\epsilon$ встановлення контакту між спе- ціалістом і дитиною, що сприяє глибшому розкриттю психологічних особливостей та потенціалу розвитку дитини.

5. Аналіз отриманих у ході дослідження результатів, спостережень спеціаліста та наявної історії розвитку дитини. На цьому кроці важливим є не лише встановити сфери, у яких дитина має труднощі (слабкі сторони розвитку), а ще і визначити потенціал дитини (сильні сторони розвитку), з урахуванням якого можна побудувати індивідуальний освітній маршрут дитини 3 особливими освітніми потребами.

6. Написання наративного звіту та рекомендацій для побудови подальшого освітнього маршруту дитини та напрямів роботи фахівців із нею.

7. Ознайомлення батьків або законних представників дитини з результатами дослідження, надання рекомендацій для побудови подальшої взаємодії з дитиною та окреслення напрямів роботи фахівців.

Запропонований алгоритм роботи практичного психолога інклюзивно-ресурсного центру щодо здійснення оцінки когнітивної та емоційно-вольової сфер дитини iз застосуванням комплекту психодіагностичних методик не є вичерпним, а являє собою узагальнення етапів роботи спеціаліста.

Висновки. Проаналізувавши особливості проведення комплексної психолого-педагогічної оцінки рівня розвитку дитини в умовах інклюзивно-ресурсного центру та охарактеризувавши комплект психодіагностичних методик, рекомендованих для iii проведення, автор окреслив сфери застосування цих інструментів у професійній діяльності практичного психолога інклюзивно-ресурсного центру та висвітлив можливості діагностики актуального рівня розвитку, а також проявів найбільш поширених нині особливостей навчально-пізнавальної діяльності дітей 3 особливими освітніми потребами, які мають значний вплив на успішність їхнього навчання та соціалізації. У розвідці запропоновано алгоритм роботи практичного психолога щодо здійснення оцінки когні- 
тивної та емоційно-вольової сфер дитини в процесі здійснення Комплексної оцінки iз застосуванням комплекту психодіагностичних методик.

Перспективи подальших розробок вбачаємо у поглибленому й докладному дослідженні практичних аспектів використання комплекту психодіагностичних методик, рекомендованих для проведення комплексної оцінки розвитку дітей з особливими освітніми потребами, у роботі 3 дітьми різних категорій особливих освітніх потреб, зокрема з РАС та РДУГ; вивченні особливостей професійної підготовки та підвищення кваліфікації фахівців інклюзивно-ресурсних центрів у процесі оволодіння необхідним набором навичок у роботі зі згаданими методиками.

\section{ЛІТЕРАТУРА}

1. Векслер Д. Шкала інтелекту Векслера для дітей: керівництво з проведення та підрахунку результатів тесту / Л. Бурлачук, О. Орел, К. Шкуропат, В. Шумакова, Міськова О. - ТОВ «ОС Україна», 2018. - 204 с.

2. Гейл Х. Ройд, Люсі Дж. Міллер, Марк Помплан та Кріс Кох. Міжнародна шкала продуктивності Лейтера. Третє видання. - Київ : ОС Україна.

3. Івашура Н. С., Ангелова А. В. Методичні рекомендації для педагогів загальноосвітніх навчальних закладів / Н. С. Івашура, А. В. Ангелова - Харків : Вид-во «Ранок», ВГ «Кенгуру», 2018. - 48 с.

4. Ілляшенко Т. І. Визначення загальних засад психологічного супроводу дітей із затримкою психічного розвитку на основі узагальнення досліджень вчених країн пострадянського простору / Т. І. Ілляшенко / Журнал «Психологічний часопис». Том 6, № 11, 2020. - C. 93-103. DOI: 10.31108/1.2020.6.11

5. Консультативно-діагностичний супровід дітей з особливими освітніми потребами в діяльності психолого-медико-педагогічних консультацій: посіб. / Жук Т. В., Ілляшенко Т. Д., Луценко І. В. та ін..; за ред. А. Г. Обухівської. - К. : УНМЦ практичної психології і соціальної роботи, 2016. - 248 с.

6. Маєс С. Д. CASD - опитувальник розладів аутистичного спектра: керівництво / Переклад з англ. О. Литвиненко. - К. : ТОВ «ОС Україна» (Giunti Psychometrics Ukraine), 2013. $-36 \mathrm{c}$.

7. Наказ Міністерства освіти і науки України від 17.05.2019 р. № 671 «Про деякі питання організації навчання фахівців інклюзивно-ресурсних центрів».

8. Обухівська А. Г. Методичні та організаційні питання діагностико-консультативної діяльності психолого-медико-педагогічних консультацій / Обухівська А. Г., Ілляшенко А. Г., Жук Т. В. та ін. - Київ : УНМЦ практичної психології і соціальної роботи, 2017. - C. 78.

9. Обухівська А. Г. Психолого-педагогічне вивчення навчальних компетентностей дошкільників з особливими освітніми потребами / А. Г. Обухівська / Харківський осінній марафон психотехнологій - 2019 : Частина 2. Тези доповідей, 2019. - С. 171.

10. Організаційно-методичні засади діяльності інклюзивно-ресурсних центрів : навчально-методичний посібник / За заг. ред. М. А. Порошенко та ін. - Київ : 2018. - 252 с.

11. Постанова Кабінету Міністрів України від 12 липня 2017 р. № 545 «Про затвердження Положення про інклюзивно-ресурсний центр».

12. Keith Conners, С. Керівництво Conners-3. Conners третє видання / Адаптація української версії тесту О. Орел, О. Кришовська. - К. : ТОВ «ОС Україна» (GiuntiPsychometricsUkraine), 2017. - 220 c. 


\title{
СОВРЕМЕННЫЕ МЕТОДЫ ДИАГНОСТИКИ УРОВНЯ РАЗВИТИЯ ДЕТЕЙ С ОСОБЫМИ ОБРАЗОВАТЕЛЬНЫМИ ПОТРЕБНОСТЯМИ
}

\author{
Шашлова Анастасия, \\ методист областного ресурсного ијентра \\ по поддержке инклюзивного образования \\ Николаевский областной институт \\ последипломного педагогического образования \\ ул. Адмиральская, 4-а, 54001, г. Николаев, Украина \\ anastasiia.shashlova@moippo.mk.ua
}

В статье проанализированы особенности проведения комплексной психолого-педагогической оченки развития ребенка с особыми образовательными потребностями в условиях инклюзивно-ресурсного иентра с применением современных психодиагностических методик, которые соответствуют мировым стандартам психодиагностики и являются адаптированньли для использования на территории Украины.

Охарактеризован комплект лицензионного психодиагностического инструментария для исследования уровня развития детей с особыми образовательными потребностями, рекомендованного, в частности, для проведения комплексной оценки развития детей с особыми образовательными потребностями в условиях инклюзивно-ресурсного иентра.

Предложен алгоритм работы психолога по осуществлению оченки когнитивной и эмочионально-волевой сфер ребенка в процессе осуществления комплексной оценки развития ребенка с особыми образовательными потребностями с применением комплекта психодиагностических методик.

Ключевые слова: дети с особыми образовательными потребностями; индивидуальные особенности; комплексная психолого-педагогическая оценка развития; особенности психофизического развития; психодиагностические методики; психодиагностическое исследование.

\section{MODERN DIAGNOSIS METHODS OF DEVELOPMENT LEVEL OF CHILD WITH SPECIAL EDUCATIONAL NEEDS}

\author{
Shashlova Anastasia, \\ educator, \\ the regional Center \\ to support inclusive education \\ Mykolaiv In-Service Teachers Training Institute \\ Admiralska Street, 4-a, 54001, Mykolaiv, Ukraine \\ anastasiia.shashlova@moippo.mk.ua
}

The article analyzes and summarizes the comprehensive psychological and pedagogical assessment of child development with special educational needs in the Inclusive Resource Center using modern psychodiagnostic techniques that are globally recognized and adapted in Ukraine.

A set of licensed psychodiagnostic tools for recognizing the child's development level is recommended, including methods for determining the mental development level and child's cognitive activity with autism spectrum disorders, as well as a psychodiagnostic questionnaire to identify the child's attention deficit hyperactivity disorder.

An algorithm of psychologist's work on the assessment of cognitive, emotional and 
volitional spheres of a child with special educational needs is proposed.

Keywords: children with special educational needs; comprehensive psychological and pedagogical assessment of development; individual features; features of psychophysical development; psychodiagnostic research; psychodiagnostic techniques.

\section{REFERENCES}

1. Illiashenko, T. I. (2020). Vyznachennia zahalnykh zasad psykholohichnoho suprovodu ditei iz zatrymkoiu psykhichnoho rozvytku na osnovi uzahalnennia doslidzhen vchenykh krain postradianskoho prostoru [Determining the general principles of psychological support of children with mental retardation based on the generalization of research by scientists in the post-Soviet space]. Zhurnal «Psykholohichnyi chasopys», Tom 6 № 11, 93-103. DOI: 10.31108/1.2020.6.11 (ukr).

2. Ivashura, N. S. \& Anhelova, A. V. (2018). Metodychni rekomendatsii dlia pedahohiv zahalnoosvitnikh navchalnykh zakladiv [Methodical recommendations for teachers of secondary schools]. Kharkiv: Vyd-vo «Ranok», VH «Kenhuru» (ukr).

3. Keith Conners, C. (2017). Kerivnytstvo Conners-3. Conners tretie vydannia / Adaptatsiia ukrainskoi versii testu O. Orel, O. Kryshovska [Conners-3 Guide. Conners third edition]. K.: TOV «OS Ukraina» (Giunti Psychometrics Ukraine) (ukr).

4. Maies, S. D. (2013). CASD - opytuvalnyk rozladiv autystychnoho spektra: kerivnytstvo [CASD Autism Spectrum Disorders Questionnaire: A Guide]. K.: TOV «OS Ukraina» (GiuntiPsychometricsUkraine) (ukr).

5. Obukhivska, A. H., Illiashenko, A. H. \& Zhuk, T. V. (2017). Metodychni ta orhanizatsiini pytannia diahnostyko-konsultatyvnoi diialnosti psykholoho-medyko-pedahohichnykh konsultatsii [Methodical and organizational issues of diagnostic-consultative activity of psychological-medical-pedagogical consultations]. Kyiv: UNMTs praktychnoi psykholohii i sotsialnoi roboty (ukr).

6. Obukhivska, A. H. (2019). Psykholoho-pedahohichne vyvchennia navchalnykh kompetentnostei doshkilnykiv $\mathrm{z}$ osoblyvymy osvitnimy potrebamy [Psychological and pedagogical study of educational competencies of preschoolers with special educational needs]. Kharkiv: Kharkivskyi osinnii marafon psykhotekhnolohii: Chastyna 2, 171-179 (ukr).

7. Order of the Ministry of Education and Science of Ukraine «On some issues of training of specialists of inclusive resource centers» № 671 (2019, May 17) (ukr).

8. Poroshenko, M. A. (2018). Orhanizatsiino-metodychni zasady diialnosti inkliuzyvnoresursnykh tsentriv [Organizational and methodical bases of activity of inclusive resource centers]. Kyiv (ukr).

9. Resolution of the Cabinet of Ministers of Ukraine «On approval of the Regulations on the inclusive resource center» № 545 (2017, July 12) (ukr).

10. Roid, H., Miller, L., Pomplan, M. \& Kokh, K. (2013). Mizhnarodna shkala produktyvnosti Leitera [Leiter International Productivity Scale]. Tretie vydannia. K: TOV «OS Ukraine» (ukr).

11. Veksler, D. (2018). Shkala intelektu Vekslera dlia ditei: kerivnytstvo z provedennia ta pidrakhunku rezultativ testu / Burlachuk, L., Orel, O., Shkuropat, K., Shumakova, V., Miskova, O. [Wechsler Intelligence Scale for Children: A Guide to Conducting and Calculating Test Results]. K.: TOV «OS Ukraina» (ukr).

12. Zhuk, T. V., Illiashenko, T. D. \& Lutsenko, I. V. (2016). Consultative and diagnostic support of children with special educational needs in the activities of psychological, medical and pedagogical consultations: manual [Consultative and diagnostic support of children with special educational needs in the activities of psychological, medical and pedagogical consultations]. Kyiv: UNMC of Practical Psychology and Social Work (ukr). 